and orthopaedic clinics. Patients referred for a specialist opinion may be expected to have a longer duration of symptoms than general-practitioner patients, and this was confirmed from our data. Several other features, however, were identified as being significantly worse in this group of patients. Mobilisation and manipulation probably hasten improvements that are likely to occur anyway. Our failure to show any benefit from mobilisation and manipulation in this series was probably due to the patients likely to benefit being those most likely to improve spontaneously and being selected out by the delay before being seen.

We thank Mr K Lucas and Mr P Stableforth for allowing us to see patients under their care. This study was performed with the aid of a grant from the Department of Health and Social Security, to whom we are most grateful.

Requests for reprints should be sent to Professor M I V Jayson.

\section{References}

${ }^{1}$ Sims-Williams, H, et al, British Medical fournal, 1978, 2, 1338.

2 Maitland, G D, Vertebral Manipulation, 4th edn. London, Butterworths, 1977.

${ }^{3}$ Loebl, W Y, Annals of Physical Medicine, 1967, 9, 103.

${ }^{4}$ Reynolds, P M G, Rheumatology and Rehabilitation, 1975, 14, 180.

(Accepted 11 September 1979)

\title{
Bacterial contamination of expressed breast milk
}

\author{
CATRYN LLOYD JONES, R F JENNISON, S W D'SOUZA
}

British Medical fournal, 1979, 2, 1320-1322

\section{Summary and conclusions}

In a study of breast milk collected into sterile bottles rinsed in $1 \%$ hypochlorite solution the hypochlorite solution adherent to the sides of the bottles apparently caused a large reduction in bacterial contamination of the milk after storage at $4^{\circ} \mathrm{C}$ for up to four hours. Heating expressed breast milk at $62 \cdot 5^{\circ} \mathrm{C}$ for five minutes destroyed over $90 \%$ of the Escherichia coli, Staphylococcus aureus, and group $B$ beta-haemolytic streptococci inoculated into the milk samples.

Rinsing collecting bottles with hypochlorite solution may be valuable in collecting milk with a low bacterial content for human-milk banks. Furthermore, the currently accepted pasteurisation time of 30 minutes may be excessive.

\section{Introduction}

The protective effect of breast-feeding against infection has been recognised for many years, particularly in relation to enteric diseases. Conserving the anti-infective properties of breast milk and providing milk that is not contaminated by pathogenic bacteria, however, pose practical problems of collection and storage. At present, milk stored in breast-milk banks has been sterilised, boiled, or, more commonly, pasteurised at the standard $62.5^{\circ} \mathrm{C}$ for 30 minutes to destroy any pathogenic bacteria. Nevertheless, heating the milk in this way affects certain protective substances such as IgA and lactoferrin. ${ }^{1}$ Hence the less severe the heat treatment the greater the chance that these substances will be conserved. We undertook the present study to find whether the standard pasteurisation time of 30 minutes is excessive for making expressed breast milk bacteriologically safe. The organisms studied were the pathogenic bacteria found

St Mary's Hospital, Manchester M13 0JH

CATRYN LLOYD JONES, BSC, research student, university department of child health

R F JENNISON, MD, FRCPATH, consultant clinical pathologist

S W D'SOUZA, PHD, MRCP, senior lecturer in child health and consultant paediatrician by Lucas and Roberts ${ }^{2}$ to be growing in untreated human milknamely, Escherichia coli, Staphylococcus aureus, and group B $\beta$-haemolytic streptococci. Lucas and Roberts ${ }^{2}$ also reported that milk collected in vessels rinsed in hypochlorite solution contained fewer bacteria than milk collected in vessels washed in ordinary detergent. We investigated this further to find whether the hypochlorite solution adhering to the sides of the vessels acted in a bacteriostatic way.

\section{Methods}

Expressed breast milk was donated by mothers who had given birth at this hospital. Each donor was instructed on how to collect the milk hygienically, which included washing the hands and breasts before collection.

Rinsing collecting bottles with hypochlorite solution-Each donor was given two identical $20 \mathrm{ml}$ glass bottles with screw caps, both bottles having been autoclaved at $121^{\circ} \mathrm{C}$. One bottle served as a control and the other has been washed in $1 \%(\mathrm{w} / \mathrm{v})$ sodium hypochlorite solution (Milton Crystals). The donor expressed about $10 \mathrm{ml}$ milk from the same breast into each bottle. To avoid bias when doing bacterial counts the investigator (CLJ) was not told which bottles had been washed in hypochlorite solution. Viable bacterial counts were carried out on paired samples of milk within four hours of collection, during which time the milk was stored at $4^{\circ} \mathrm{C}$.

Heating at $62.5^{\circ} \mathrm{C}$-Expressed breast-milk samples $(15-20 \mathrm{ml})$ were collected in similar glass bottles to those that had been autoclaved and rinsed in hypochlorite solution. The milk was stored in a refrigerator, and within four hours of collection an aliquot was inoculated with either $E$ coli, Staph aureus, or group B $\beta$-haemolytic streptococci. A concentration of about $10^{6}$ organisms $/ \mathrm{ml}$ was decided as sufficient. The inoculated milk $(7.5 \mathrm{ml})$ was heated in a waterbath at $62 \cdot 5 \pm 0 \cdot 1{ }^{\circ} \mathrm{C}$ and viable bacterial counts carried out at intervals of five, 10, 20, and 30 minutes. Inoculated agar plates were incubated for 14 hours at $37^{\circ} \mathrm{C}$. This procedure was repeated six times for each pathogen and the percentage destruction of bacteria after heating calculated.

Preparation of inoculum-Brown's tubes for standardising bacterial vaccines were used. The bacterial suspension was diluted to $10^{7.5}$ organisms $/ \mathrm{ml}$, and $1 \mathrm{ml}$ of this suspension then diluted in $6.5 \mathrm{ml}$ breast milk to give a suspension of about $10^{6}$ organisms $/ \mathrm{ml}$.

Viable bacterial counts were carried out by the Miles and Misra method, as described by Baker and Breach ${ }^{3}$ and Cruickshank et al.

\section{Results}

Effect of hypochlorite solution on bacterial contamination-Milk collected in ordinary sterile bottles had higher bacterial counts than 
milk collected in sterile bottles washed with hypochlorite solution (table I). No bacterial colonies were cultured from specimens collected from mothers $\mathrm{A}, \mathrm{C}$, and $\mathrm{E}$ in sterile bottles washed with hypochlorite solution, but the corresponding specimens collected in the ordinary sterile bottles had bacterial counts of 330, 66000, and 540000 organisms $/ \mathrm{ml}$. In the remaining specimens washing the sterile bottles with hypochlorite solution reduced the bacterial counts by $22-75 \%$.

TABLE I-Number of organisms/ml in expressed breast milk collected from donors $A$ to $G$ in sterile bottles and in sterile bottles washed with $1 \%$ hypochlorite solution

\begin{tabular}{lrrrrrrc}
\hline & \multicolumn{7}{c}{ Donor } \\
\cline { 2 - 8 } Bottles & $\mathrm{A}$ & $\mathrm{B}$ & $\mathrm{C}$ & \multicolumn{1}{c}{$\mathrm{D}$} & $\mathrm{E}$ & $\mathrm{F}$ & $\mathrm{G}$ \\
\hline Sterile & 330 & 8100 & 66000 & 2400 & 540000 & 1500 & 180000 \\
$\begin{array}{l}\text { Sterile and } \\
\text { hypochlorite }\end{array}$ & 0 & 6300 & 0 & 600 & 0 & 900 & 48000 \\
\hline Difference & 330 & 1800 & 66000 & 1800 & 540000 & 600 & 132000 \\
\hline
\end{tabular}

The bacterial counts for the two sets of bottles were compared statistically. The growth of bacterial colonies on a plate of culture medium has a Poisson distribution. ${ }^{5}$ We used the log values of the bacterial counts, and comparisons of their mean values showed that the difference between the two sets of bottles was highly significant $(P<0.01)$. The mean $\log$ bacterial count in milk collected in ordinary sterile bottles was 4.1129 SE0.4146 and in milk collected in sterile bottles rinsed in hypochlorite solution $2 \cdot 0303 \pm 0 \cdot 4883$.

Effect on $E$ coli of heating at $62.5^{\circ} \mathrm{C}$-Heating to $62.5^{\circ} \mathrm{C}$ milk inoculated with $E$ Coli destroyed most of the organisms after five minutes (table II), and after 10 minutes destruction was complete in all except one sample. The percentage destruction after five minutes ranged from $99.73^{\circ}$, to $99.99 \%$ in the six samples of milk, the mean being $99.88 \ldots$ SE $0.03^{\circ}$ 。.

TABLE II-Number of Escherichia coli organisms/ml in expressed breast milk from donors $A$ to $F$ after periods of heating at $62.5^{\circ} \mathrm{C}$

\begin{tabular}{lcccccc}
\hline $\begin{array}{c}\text { Time after } \\
\text { inoculation } \\
\text { (minutes) }\end{array}$ & $\mathrm{A}$ & $\mathrm{B}$ & $\mathrm{C}$ & $\mathrm{D}$ & $\mathrm{E}$ & $\mathrm{F}$ \\
\hline 0 & $0.65 \times 10^{6}$ & $1 \cdot 1 \times 10^{6}$ & $1 \cdot 0 \times 10^{6}$ & $0.5 \times 10^{6}$ & $0.8 \times 10^{\circ}$ & $1.2 \times 10^{\circ}$ \\
5 & 50 & 1500 & 1500 & 500 & 800 & 450 \\
10 & 0 & 0 & 0 & 0 & 0 & 0 \\
20 & 0 & 0 & 0 & 0 & 0 & 0 \\
30 & 0 & 0 & 0 & 0 & 0 & 0 \\
\hline
\end{tabular}

Effect on Staph aureus of heating at $62 \cdot 5^{\circ} \mathrm{C}$-Heating at $62 \cdot 5^{\circ} \mathrm{C}$ for five minutes destroyed most of the organisms in milk inoculated with Staph aureus, and after 10 minutes destruction was complete in all but one sample (table III). The percentage destruction after five minutes ranged from $96.66 \%$ to $99.99 \%$ in the six samples, the mean being $99.41+0.5 \%$.

TABLE III-Number of Staphylococcus aureus organisms $/ m l$ in expressed breast milk from donors $A$ to $F$ after periods of heating at $62 \cdot 5^{\circ} \mathrm{C}$

\begin{tabular}{ccccccc}
\hline $\begin{array}{c}\text { Time after } \\
\text { inoculation } \\
\text { (minutes) }\end{array}$ & $\mathrm{A}$ & $\mathrm{B}$ & $\mathrm{C}$ & $\mathrm{D}$ & $\mathrm{E}$ & $\mathrm{F}$ \\
\hline 0 & $1 \cdot 2 \times 10^{6}$ & $7.5 \times 10^{6}$ & $1.3 \times 10^{6}$ & $0.9 \times 10^{\circ}$ & $4.5 \times 10^{\circ}$ & $0.9 \times 10^{\circ}$ \\
5 & 550 & 250000 & 350 & 350 & 150 & 50 \\
10 & 0 & 500 & 0 & 0 & 0 & 0 \\
20 & 0 & 0 & 0 & 0 & 0 & 0 \\
30 & 0 & 0 & 0 & 0 & 0 & 0 \\
\hline
\end{tabular}

Effect of heating at $62.5^{\circ} \mathrm{C}$ on group $B$-haemolytic streptococciMost of the organisms in milk inoculated with group $B \beta$-haemolytic streptococci were destroyed by heating for five minutes at $62 \cdot 5^{\circ} \mathrm{C}$. This organism seemed to behave differently from the other two pathogens because in three of the milk samples a few survived heating for 30 minutes (table IV). The percentage destruction after five minutes ranged from $95.83 \%$ to $100 \%$ in the six samples, the mean being $99.30 \pm 0.63 \%$.

For all three pathogens the higher the initial bacterial count the longer heating was needed for complete destruction.

\section{Discussion}

Much research into collecting and processing human milk is aimed at producing a microbiologically safe material that also retains as many as possible of the protective and other qualities of fresh breast milk. The importance of hygiene and cleanliness in collecting expressed breast milk has been widely emphasised. Particularly interesting is the work of Lucas and Roberts, ${ }^{2}$ who found that home sterilisation of collecting bottles using hypochlorite solution significantly reduced the bacterial contamination of expressed breast milk. Our study questions the reason for this: was it due to the bottles themselves being sterilised by

TABLE IV-Number of group $B$-haemolytic streptococci/ml in expressed breast milk from donors $A$ to $F$ after periods of heating at $62.5^{\circ} \mathrm{C}$

\begin{tabular}{|c|c|c|c|c|c|c|}
\hline \multirow{2}{*}{$\begin{array}{c}\text { Time after } \\
\text { inoculation } \\
\text { (minutes) }\end{array}$} & \multicolumn{6}{|c|}{ Donor } \\
\hline & A & B & C & $\mathrm{D}$ & E & $F$ \\
\hline $\begin{array}{l}0 \\
5 \\
10 \\
20 \\
30\end{array}$ & $\begin{array}{c}12 \cdot 3 \times 10^{6} \\
120 \\
300 \\
300 \\
0\end{array}$ & $\begin{array}{c}2 \cdot 7 \times 10^{6} \\
0 \\
0 \\
0 \\
30\end{array}$ & $\begin{array}{c}1.8 \times 10^{6} \\
0 \\
30 \\
0 \\
0\end{array}$ & $\begin{array}{c}2 \cdot 1 \times 10^{6} \\
30 \\
30 \\
0 \\
30\end{array}$ & $\begin{array}{c}0.99 \times 10^{6} \\
60 \\
0 \\
0 \\
0\end{array}$ & $\begin{array}{r}7 \cdot 2 \times 10^{6} \\
300000 \\
3000 \\
60 \\
90\end{array}$ \\
\hline
\end{tabular}

the hypochlorite solution, or to the hypochlorite solution adhering to the walls of the vessel, thus actively destroying bacteria present in the milk?

Our results suggest that hypochlorite solution adhering to the inner surfaces of the glass bottles was responsible for the reduced bacterial counts in the milk samples. The proportion of organisms destroyed by hypochlorite bore no relation to bacterial counts in control specimens (table I). Hence some bacteria contaminating donated milk may be more sensitive to hypochlorite than others.

Side effects in the baby resulting from using $1 \%$ hypochlorite solution have, to our knowledge, never been reported, so toxicity seems unlikely to occur. Hypochlorite solution may alter the constituents in breast milk, which warrants further investigation, especially with regard to the important protective substances in the milk.

Throughout the history of human-milk banking various methods have been used to sterilise donated milk. These have included boiling and pasteurising by the the "flash" and holder methods. These methods, however, may damage the protective substances in milk. ${ }^{8} 7$ The holder process was designed by the dairy industry to ensure destruction of Mycobacterium tuberculosis, which is sometimes found in cows' milk, and was adopted by human-milk banks as a convenient process. Our results suggest that the accepted time of 30 minutes for heating is excessive. Only five minutes of heating at $62.5^{\circ} \mathrm{C}$ resulted in a mean reduction of over $90 \%$ in the initial concentration of bacteria. Any remaining bacteria would be at such low concentrations that they would probably be harmless to the baby.

A trend in the results suggests that the higher the contamination of milk the longer it takes to achieve sterility. This would not constitute a hazard in milk banks because highly contaminated milk is discarded and milk from all donors is pooled, thus diluting a high level of contamination in one sample.

Group B $\beta$-haemolytic streptococci were more resistant to destruction by heating than the other pathogens. In some milk samples a few of these streptococci survived even after heating at $62.5^{\circ} \mathrm{C}$ for 30 minutes, whereas complete sterility was obtained by heating for 10 minutes in most samples inoculated with $E$ coli or Staph aureus. Continued study to determine a reason for this greater resistance to heating would be interesting. Although more group B $\beta$-haemolytic streptococci survived for longer periods of heating at $62.5^{\circ} \mathrm{C}$ than the other pathogens, the percentage destroyed after heating for five minutes was about the same.

Since bacterial pathogens commonly contaminating human milk may be eliminated after heating for only five minutes at 
$62.5^{\circ} \mathrm{C}$ the holder pasteurisation time of 30 minutes seems unnecessary. We were not concerned about less thermolabile organisms, since they tend to be of unlikely pathogenicity or spore-forming. Mycobacteria are not common pathogens in human milk. We intend to investigate whether a shorter heating time will conserve a higher proportion of immunologically active substances in milk. Ford et $\mathrm{al}^{7}$ reported that heating milk for $\mathbf{3 0}$ minutes at $62.5^{\circ} \mathrm{C}$ reduced the IgA titre by $20 \%$ and destroyed the small amount of IgM and most of the lactoferrin.

We thank Miss Valerie Hooton for her constant help in supervising the experimental work.

\section{References}

${ }^{1}$ British Medical fournal, 1978, 1, 1372.

2 Lucas, A, and Roberts, C D, British Medical fournal, 1979, 1, 80.

${ }^{3}$ Baker, F J, and Breach, M R, Handbook of Bacteriological Technique, 2nd edn, p 209. London, Butterworths, 1967.

${ }^{4}$ Cruickshank, R, et al, Medical Microbiology, 12th edn, vol 2, p 307. Edinburgh, Churchill Livingstone, 1975.

5 Armitage, P, Statistical Methods in Medical Research, p 66. Oxford and Edinburgh, Blackwell Scientific Publications, 1971.

${ }^{6}$ Raptopoulou-Gigi, M, Marwick, K, and McClelland, D B L, British Medical Fournal, 1977, 1, 12.

${ }^{7}$ Ford, J E, et al, fournal of Pediatrics, 1977, 90, 29.

(Accepted 11 September 1979)

\title{
How reliable is determination of ulcer size by endoscopy?
}

\author{
A SONNENBERG, M GIGER, L KERN, C NOLL, K STUBY, K B WEBER, A L BLUM
}

British Medical fournal, 1979, 2, 1322-1324

\section{Summary and conclusions}

The surface areas of 23 artificial ulcers in a rubber manikin and of 35 ulcers in 35 consecutive patients admitted for endoscopy of the upper gastrointestinal tract were estimated by six endoscopists. Of the 138 estimations made in the manikin $80 \%$ underestimated the true size of the ulcer: the mean $( \pm S D)$ was $-29 \pm 40 \%$. The largest and the smallest estimate of the same ulcer by different endoscopists varied on average by a factor of $4.5 \pm 3.8$, and the estimates by the same endoscopists of ulcers with the same size varied by a factor of $2 \cdot 3 \pm 0.6$. In the patients the scatter of the estimates was even larger, the mean factor being $7 \cdot 8 \pm 6 \cdot 3$. Changes in ulcer size are therefore an unsuitable criterion for assessing ulcer healing. Even if consecutive examinations are performed by the same endoscopist, changes in ulcer area smaller than by a factor of 3 are not discernible.

\section{Introduction}

In many controlled clinical trials of treatment for peptic lesions changes in the size of an ulcer have been used as an index of ulcer healing. ${ }^{1-7}$ We decided to test the reliability of the determination of ulcer size by fibreoptic endoscopy.

\section{Methods}

In-vitro studies-In a rubber manikin consisting of head, oesophagus, stomach, and duodenum ${ }^{8}$ (OGI Phantom, Coburger Lehrmittelanstalt, W Germany) 23 artificial, consecutively numbered peptic lesions were produced. The lesions were excavated with a sharp spoon and painted white with water-insoluble paint. The two

Triemli Hospital, CH-8063 Zurich, Switzerland

A SONNENBERG, MD, physician

M GIGER, MD, physician

L KERN, MD, physician

C NOLL, MD, physician

K STUBY, MD, physician

K B WEBER, MD, physician

A L BLUM, MD, physician largest orthogonal diameters ( $a$ and $b$ ) of each ulcer were measured with a vernier caliper. The area of the ulcer $(A)$ was calculated as:

$$
\mathrm{A}=\frac{\pi \mathrm{ab}}{4}
$$

The areas of the ulcers were estimated on six different days by six endoscopists using a fibreoptic endoscope. Three "experienced" endoscopists had performed more than 1000 endoscopies before entering the trial, and three "beginners" had performed between 100 and 500 endoscopies. No endoscopist had access to the values determined by the others. The endoscopies were performed with the endoscopes GIF D II, GIF P II, and GIF K from Olympus. Every endoscopist was free to choose the instrument(s) he liked. Usually several instruments were used simultaneously. The width of closed and opened biopsy forceps served as reference length. The deviation (D) of the estimated ulcer area (A') from the true ulcer area (A) was calculated as follows:

$$
\mathrm{D}=\frac{\mathrm{A}-\mathbf{A}^{\prime}}{\mathrm{A}}
$$

The absolute value of $\mathrm{D}$ ([D]) was named absolute deviation.

In-vivo study-In 35 patients with an ulcer but no other disease who gave informed consent and tolerated endoscopy well the size of a peptic lesion in stomach or duodenum was estimated by the same endoscopists who had participated in the in-vitro study. To estimate the size of the ulcer every endoscopist was handed the endoscope and manoeuvred it by himself. He then noted the ulcer size on a sheet, dropped the sheet into a locked letter box, and left the room without telling others his findings. The area of the ulcer was calculated in the same way as for the artificial ulcers. In five additional patients ulcers were measured with a measuring rod (ACMI), which could be inserted through the biopsy channel.

Comparison of in-vivo and in-vitro results-Since no information on the true size of the patients' ulcers was obtainable, the following values were used which could be obtained for both the artificial and the real ulcers. An assessment of scatter (S) of the data was the ratio of the standard deviation (SD) over the average estimate of each ulcer area $\left(\overline{\mathrm{A}}^{\prime}\right): \mathrm{S}=\mathrm{SD} / \overline{\mathrm{A}}^{\prime}$. A second assessment of scatter was the ratio $(R)$ of the largest $\left(A^{\prime}{ }_{\max }\right)$ over the smallest $\left(A^{\prime} \min \right)$ estimate of the ulcer size: $R=A^{\prime}{ }_{\max } / A^{\prime}{ }_{m ! n}$. The estimation characteristic $(C)$ of each endoscopist was described by the deviation of his personal mean of 35 estimates (m) from the mean of all 210 estimates (M): $\mathrm{C}=(\mathrm{m}-\mathrm{M}) / \mathrm{M}$.

\section{Results}

In-vitro studies-Of the 138 estimates of ulcer size, $111(80 \%)$ were too small, and this tendency to underestimate ulcer size was statistically significant $\left(\chi^{2}=61 ; \mathrm{Df}=2 ; \mathrm{P}<0.001\right)$. In only 18 cases 